\title{
PREVALENCE OF OCCUPATIONAL STRESS AND DEPRESSION AMONG SCHOOL TEACHERS
}

\author{
By \\ Khalifa EM ${ }^{1}$, Khalaf $\mathrm{OO}^{2}$ and Mohammed $\mathrm{RS}^{1}$ \\ ${ }^{1}$ Department of Occupational and Environmental Medicine, ${ }^{2}$ Department of Psychiatry, \\ Faculty of Medicine, Cairo University, Egypt.
}

Corresponding author: Mohammed RS, Email: rateba.said@kasralainy.edu.eg,ratebasaid@hotmail.com

DOI: $10.21608 /$ ejom.2021.76784.1237

Submit Date: 2021-05-21

Revise Date: 2021-06-13

Accept Date: 2021-06-22

Authors'contribution: Authors contributed equally to this work.

\begin{abstract}
Introduction: Teaching has been listed among the highest stressful jobs. Several occupational stressors were detected in the school environment such as class size, work overload, student bad behavior and a lack of their appreciation Aim of Work: To determine the prevalence of occupational stress and depression symptoms among school teachers and the relation between them, to identify the different occupational stressors in the school environment, to detect the prevalence of physical symptoms and their relationship to occupational stress and depression symptoms. Materials and Methods: Socio-demographic data, occupational and medical histories of many physical symptoms were collected by researchers and self administered Arabic version of Occupational Stress Index (OSI) and Beck Depression Inventory (BDI) questionnaires were used to assess the prevalence of occupational stress and depression symptoms respectively. Results: All teachers were complaining of stress; mainly of moderate level (55.7\%), while the prevalence of depression symptoms was (19.8\%). Role overload, role conflict, unreasonable group and political pressures were the most occupational stressors found among the studied population. As regards private school teachers, responsibility for persons was the most significant stressor while powerlessness, poor peer relationship, intrinsic impoverishment and low status were significant stressors among governmental school teachers. Positive correlations were found between these occupational stressors and depression symptoms. Many physical symptoms were significantly prevalent among teachers with higher scores of OSI and BDI. Conclusion: Teachers had a high prevalence of occupational stress due to exposure to many occupational stressors. Depression and stress related physical symptoms were
\end{abstract}


serious consequences of occupational stress that needs early psychological intervention and collaboration between different sectors of educational system for their wellbeing and better performance.

Keywords: School teachers, Occupational stress, Depression symptoms and Somatic disorders.

\section{Introduction}

Occupational stress is a harmful work-related condition that occurs when workers' capabilities and resources did not meet their work demands and requirements, so they experience physical and emotional stress (Mursali et al., 2009). Teaching is a very exhausting and stressful occupation; it has been listed among the highest stressful jobs (Schwarzer and Hallum, 2008) Several stressful factors were identified at school environment as class size, work overload, lack of planning time and paperwork (Liu and Ramsey, 2008). They also have to satisfy the needs of parents, students, colleagues and their administrators in the presence of increasing roles, student bad behavior and lack of appreciation of their achievements (Greenglass and Burke, 2003 and Kapse et al., 2010). Chronic exposure to stressful condition at work leads to several mental disorders such as anxiety and depression with increased absenteeism, work-related illnesses and decline of teacher's performance; thus affects the student's learning and the whole learning process (Asa and Lasebikan, 2016). Physical health problem may be also developed as a result of chronic exposure to stress with manifestations of heart diseases, musculoskeletal and gastrointestinal symptoms (Yang et al., 2009; Harvey and Wessely, 2013). For these reasons, researches about occupational stress and its harmful effect on mental and physical wellbeing have become of great importance and are considered an interesting and a prominent topic (Naghieh et al., 2015).

\section{Aim of Work}

The aim of this study was to determine the prevalence of occupational stress and depression among school teachers and the relation between them, to identify the different occupational stressors in the school environment, to detect the prevalence of physical symptoms and their relationship to occupational stress and depression.

\section{Materials and Methods}

Study design: It is an analytical cross-sectional study. 
Place and duration of the study: The study was conducted in 2 private and 1 governmental schools in Cairo from February to June 2019.

Study sample: Sample size (106 participants) was calculated using Epicalc 2000. Assuming 80\% power, 0.05 level of significance; with response rate was $70.6 \%$ (150 teachers employed in the study and only106 who complete and return the questionnaires). They were selected from three schools at Cairo, Egypt. Two were private schools for primary, preparatory and secondary grades and one was secondary governmental school. Inclusion criteria included teachers who agreed and gave informed consent at the beginning of questionnaire, with ages between 22 and 58years old while teachers who did not give informed consent, those who had a history of depression were excluded.

\section{Study method}

All participants were subjected to the following:

\section{1-Predesigned}

interviewed questionnaire including sociodemographic history (age, gender, marital status and educational level), occupational history (teaching experience in years, working hours, type of school either private or governmental, grade level they teach). Medical history of diseases and physical symptoms as (hypertension, diabetes mellitus, headache, fatigue, musculoskeletal disorders and vision problems)

2-Self administered Arabic version of Occupational Stress Index (OSI) used previously by Desouky and Allam, 2017 to assess the level of occupational stress among teachers. It is a 46 items scale (28 positive- keyed items and 18 negative- keyed items) that were rated on a 5 point Likert scale for each statement. The scores are 5 for "Strongly agree", 4 for "Mostly agree", 3 for "Neutral (Sometimes)", 2 for "Disagree" and 1 for "Strongly disagree". OSI is subdivided into twelve subscales that represent occupational stressors at this job and they are work overload, role ambiguity, role conflict, unreasonable group and political pressures, responsibility for persons, under participation, powerlessness, poor peer relations, intrinsic impoverishment, low status, strenuous working and unprofitability. The total scores of OS among teachers were classified into: "Low stress level" (46-122), "Moderate stress level” (123- 
155), and "High stress level" (156-230) (Lim, 2013).

3-Self administered Arabic version of the Beck Depression Inventory (BDI) used by AbdelKhalek , 1998 and Beck 1961 and their colleagues to assess symptoms of depression. It consists of 21 items, there are four possible answers indicating the intensity of the symptoms, starting with its absence (0) up to high severity (3). The rating to each response ranges from 0 to 3 points. Minimum overall score is 0 points, and maximum is 63 points. Scores were classified into: "No depression" (from 0-13), "Mild depression" (14-19), "Moderate depression" (20-28) and "Severe depression" (29-63).

\section{Consent}

An informed consent was taken from all participants in the study and confidentiality was maintained.

\section{Ethical approval}

The present study was done in compliance with declaration of Helsinki and an approval from the Ethical Committee of Occupational and Environmental Medicine department at Cairo University was obtained. Also approval was taken from school managers.

\section{Data management}

All statistical analyses were carried out by using SPSS version 16 . Descriptive statistics such as mean, standard deviation and range were used to describe quantitative data while frequency and percentage were used for qualitative one. Analytical statistics including, independent t-test was used to assess the difference between the groups. Pearson correlation analysis was used to assess the relationship between depression symptoms, stress and other variables (Chan, 2003). P-value $\leq 0.05$ was considered significant. 


\section{Results}

Table (1): Socio demographic characteristics of the studied population (No :106).

\begin{tabular}{|c|c|c|}
\hline Characteristics & No & $\%$ \\
\hline $\begin{array}{l}\text { Age group/years } \\
<30 \\
30-40 \\
>40 \\
\text { Mean } \pm \mathrm{SD} \\
\text { Minimum- maximum }\end{array}$ & $\begin{array}{c}37 \\
39 \\
30 \\
36.08 \pm 9.5 \\
22-58\end{array}$ & $\begin{array}{l}34.9 \\
36.8 \\
28.3\end{array}$ \\
\hline $\begin{array}{l}\text { Gender } \\
\text { Male } \\
\text { Female }\end{array}$ & $\begin{array}{l}18 \\
88\end{array}$ & $\begin{array}{l}17 \\
83\end{array}$ \\
\hline $\begin{array}{l}\text { Marital status } \\
\text { Married } \\
\text { Unmarried }\end{array}$ & $\begin{array}{l}79 \\
27\end{array}$ & $\begin{array}{l}74.5 \\
25.5\end{array}$ \\
\hline $\begin{array}{l}\text { School type } \\
\text { Private school } \\
\text { Governmental school }\end{array}$ & $\begin{array}{l}83 \\
23\end{array}$ & $\begin{array}{l}78.3 \\
21.7\end{array}$ \\
\hline $\begin{array}{l}\text { Teaching experience /years } \\
<10 \\
10-20 \\
>20 \\
\text { Mean } \pm \text { SD }\end{array}$ & $\begin{array}{c}65 \\
25 \\
16 \\
11.01 \pm 8.77\end{array}$ & $\begin{array}{l}61.3 \\
23.6 \\
15.1\end{array}$ \\
\hline $\begin{array}{l}\text { Teaching grade } \\
\text { - Primary } \\
\text { - Preparatory } \\
\text { - Secondary } \\
\text { - Multiple }\end{array}$ & $\begin{array}{c}42 \\
6 \\
35 \\
23\end{array}$ & $\begin{array}{c}39.6 \\
5.7 \\
33.0 \\
21.7\end{array}$ \\
\hline $\begin{array}{l}\text { Occupational Stress Index (OSI) } \\
\text { - Mild } \\
\text { - Moderate } \\
\text { - Severe }\end{array}$ & $\begin{array}{l}30 \\
59 \\
17\end{array}$ & $\begin{array}{l}28.3 \\
55.7 \\
16.0\end{array}$ \\
\hline $\begin{array}{l}\text { Beck Depression Inventory (BDI) } \\
\text { - Normal } \\
\text { - Mild } \\
\text { - Moderate }\end{array}$ & $\begin{array}{l}70 \\
21 \\
15\end{array}$ & $\begin{array}{c}66 \\
19.8 \\
14.2\end{array}$ \\
\hline
\end{tabular}


Table (1) showed that $36.8 \%$ of the studied population was between $30-40$ years with mean age $36.08 \pm 9.5$. The majority was females $(83 \%)$ and most of them were married (74.5\%). As regards school type, $78.3 \%$ were working in private schools and $21.7 \%$ in governmental school. About $40 \%$ were working in primary grade. Stress with different levels was present in $100 \%$ of the studied teachers; but only $34 \%$ were complaining of depression symptoms.

Table (2): Mean and SD of Occupational Stress Index and Beck Depression Inventory scores regarding different characteristics.

\begin{tabular}{|c|c|c|}
\hline Characteristics & $\begin{array}{c}\text { Occupational Stress Index } \\
\text { scores (OSI) } \\
\text { Mean } \pm \text { SD }\end{array}$ & $\begin{array}{c}\text { Beck depression Inventory } \\
\text { scores (BDI) } \\
\text { Mean } \pm \text { SD }\end{array}$ \\
\hline $\begin{array}{l}\text { Total studied population } \\
\text { Age group/years } \\
<30 \text { ( No:37) } \\
30-40 \text { (No:39) } \\
>40 \text { (No:30) } \\
\text { p value }\end{array}$ & $\begin{aligned} & 131.41 \pm 21.58 \\
& 134.3 \pm 19.3 \\
& 129.1 \pm 21.6 \\
& 130.4 \pm 21.5 \\
& 0.56\end{aligned}$ & $\begin{array}{c}10.45 \pm 7.42 \\
10.5 \pm 7.3 \\
10.4 \pm 7.3 \\
10.3 \pm 7.9 \\
0.99\end{array}$ \\
\hline $\begin{array}{l}\text { Gender } \\
\text { Male (No:18) } \\
\text { Female (No:88) } \\
\text { P value } \\
\end{array}$ & $\begin{array}{c}122.0 \pm 28.8 \\
133.3 \pm 19.4 \\
\mathbf{0 . 0 4} * \\
\end{array}$ & $\begin{array}{c}8.8 \pm 8.2 \\
10.7 \pm 7.2 \\
0.31 \\
\end{array}$ \\
\hline $\begin{array}{l}\text { School type } \\
\text { Private school (No:83) } \\
\text { Governmental school (No:23) } \\
\text { p value }\end{array}$ & $\begin{array}{c}129.09 \pm 21.0 \\
139.7 \pm 21.8 \\
\mathbf{0 . 0 3 *} \\
\end{array}$ & $\begin{array}{c}9.49 \pm 6.8 \\
13.9 \pm 8.3 \\
\mathbf{0 . 0 1}^{*} \\
\end{array}$ \\
\hline $\begin{array}{l}\text { Teaching experience /years } \\
<10 \text { years (No:65) } \\
10-20 \text { years (No:25) } \\
>20 \text { years (No:16) } \\
\text { p value }\end{array}$ & $\begin{aligned} 132.1 & \pm 20.9 \\
125.3 & \pm 19.5 \\
138.0 & \pm 25.6 \\
0.17 & \end{aligned}$ & $\begin{array}{c}11.0 \pm 7.4 \\
7.1 \pm 5.9 \\
13.4 \pm 8.0 \\
\mathbf{0 . 0 1} * \\
\end{array}$ \\
\hline $\begin{array}{l}\text { Teaching grade } \\
\text { - Primary (No:42) } \\
\text { - Preparatory (No:6) } \\
\text { - Secondary (No:35) } \\
\text { - Multiple (No:23) } \\
\text { p value }\end{array}$ & $\begin{aligned} 134.2 & \pm 19.5 \\
116.5 & \pm 18.6 \\
133.3 & \pm 23.5 \\
127.3 & \pm 21.9 \\
0.19 & \end{aligned}$ & $\begin{array}{c}11.4 \pm 6.6 \\
5.6 \pm 3.5 \\
11.4 \pm 8.6 \\
9.00 \pm 7.0 \\
0.23\end{array}$ \\
\hline $\begin{array}{l}\text { Excess students' numbers\# } \\
\text { Yes (No:56) } \\
\text { NO (No:50) } \\
\text { p value }\end{array}$ & $\begin{array}{c}136.4 \pm 20.2 \\
125.7 \pm 21.8 \\
\mathbf{0 . 0 1 *}\end{array}$ & $\begin{array}{l}12.2 \pm 7.6 \\
8.4 \pm 6.6 \\
\mathbf{0 . 0 0 6 * *}\end{array}$ \\
\hline
\end{tabular}

*: Statistically significant

**: Highly statistically significant

\#:Average Egyptian classroom density was 47.5 students ( Sobhy ,2019) 
Table (2) showed that the mean score of OSI was $131.41 \pm 21.58$ and it was significantly higher among female teachers compared to males ( $p$ was 0.04). Concerning school type, governmental school teachers showed statistically significant higher mean score of OSI and BDI than the private school ones. The mean score of OSI and BDI were significantly higher among teachers with excess student numbers. It was also found that the mean score of BDI was significantly higher among teachers with teaching experience for more than 20 years when compared to other teaching years ( $\mathrm{p}$ was 0.01 ),

\section{Table (3): Mean and SD of Occupational Stress Index (OSI) subscales among the studied population in relation to school type.}

\begin{tabular}{|l|c|c|c|c|c|}
\hline $\begin{array}{c}\text { Occupational stressors } \\
\text { (Subscales of OSI) }\end{array}$ & $\begin{array}{c}\text { Total Mean } \pm \text { SD } \\
\text { of the studied } \\
\text { population }\end{array}$ & $\begin{array}{c}\text { Private school } \\
\text { Mean } \pm \text { SD }\end{array}$ & $\begin{array}{c}\text { Governmental } \\
\text { school } \\
\text { Mean } \pm \text { SD }\end{array}$ & T test & p value \\
\hline Role overload & $17.4 \pm 3.5$ & $17.1 \pm 3.1$ & $18.3 \pm 4.7$ & 10.6 & 0.14 \\
\hline Role ambiguity & $9.3 \pm 3.06$ & $9 . \pm 2.9$ & $10.2 \pm 3.3$ & 1.57 & 0.13 \\
\hline Role conflict & $13.7 \pm 3.5$ & $13.4 \pm 3.4$ & $14.7 \pm 3.5$ & 0.34 & 0.10 \\
\hline $\begin{array}{l}\text { Unreasonable group and } \\
\text { political pressures }\end{array}$ & $12.7 \pm 3.3$ & $12.6 \pm 3.3$ & $13.4 \pm 3.3$ & 0.92 & 0.26 \\
\hline Responsibility for persons & $12.1 \pm 2.6$ & $12.6 \pm 2.4$ & $10.5 \pm 2.6$ & 0.90 & $\mathbf{0 . 0 0 1 * *}$ \\
\hline Under participation & $11.3 \pm 3.2$ & $11.19 \pm 3.2$ & $11.78 \pm 3.3$ & 0.004 & 0.44 \\
\hline Powerlessness & $7.9 \pm 2.3$ & $7.6 \pm 1.9$ & $8.9 \pm 3.3$ & 3.89 & $\mathbf{0 . 0 2 *}$ \\
\hline Poor peer relations & $8.6 \pm 2.8$ & $8.3 \pm 2.7$ & $9.9 \pm 2.9$ & 0.001 & $\mathbf{0 . 0 1 *}$ \\
\hline Intrinsic impoverishment & $10.8 \pm 3.2$ & $10.4 \pm 3.3$ & $12.2 \pm 2.7$ & 2.15 & $\mathbf{0 . 0 1 *}$ \\
\hline Low status & $7.7 \pm 2.5$ & $7.3 \pm 2.3$ & $9.2 \pm 2.8$ & 1.09 & $\mathbf{0 . 0 0 1 * *}$ \\
\hline Strenuous working & $12.3 \pm 3.5$ & 12.23 .4 & $12.8 \pm 4.0$ & 0.027 & $(0.4)$ \\
\hline Unprofitability & $7.1 \pm 1.7$ & 1.77 .06 & $7.3 \pm 1.6$ & 0.022 & $(0.48)$ \\
\hline
\end{tabular}

$¥$ OSI: Occupational Stress Index

*: Statistically significant

**: Highly statistically significant

Table (3) showed that the highest mean value of OSI subscales was role overload $(17.4 \pm 3.5)$ which was higher among governmental school teachers than private one but it didn't reach statistically significant level. Role conflict, role ambiguity, unreasonable group and political pressures and strenuous work were higher among governmental school teachers compared to private one but with no statistically significant differences. Responsibility for persons was a statistically significant stressor among private school teachers (12.6 \pm 2.4$)$ when compared to governmental one (10.5 \pm 2.6$)$, while intrinsic 
impoverishment, poor peer relationship, low status and powerlessness subscales were significantly higher among governmental school teachers $(\mathrm{p}<0.05)$.

Table (4): Mean and SD of Occupational Stress Index (OSI) and Beck Depression Inventory scores (BDI) as regards different complaints.

\begin{tabular}{|c|c|c|}
\hline complaints & $\begin{array}{c}\text { Occupational Stress Index } \\
\text { scores } \\
\text { Mean } \pm \text { SD }\end{array}$ & $\begin{array}{c}\text { Beck Depression Inventory } \\
\text { scores } \\
\text { Mean } \pm \text { SD }\end{array}$ \\
\hline $\begin{array}{l}\text { Headache } \\
\text { Yes (No:71) } \\
\text { NO (No:35) } \\
\text { p value }\end{array}$ & $\begin{array}{c}140.4 \pm 16.9 \\
113.0 \pm 18.2 \\
<\mathbf{0 . 0 0 1} * *\end{array}$ & $\begin{array}{l}11.8 \pm 7.4 \\
7.6 \pm 6.6 \\
<\mathbf{0 . 0 0 1} * *\end{array}$ \\
\hline $\begin{array}{l}\text { Hypertension } \\
\text { Yes (No: 36) } \\
\text { NO (No: 71) } \\
\text { p value }\end{array}$ & $\begin{array}{c}141.1 \pm 23.7 \\
126.4 \pm 18.6 \\
\mathbf{0 . 0 0 1} * *\end{array}$ & $\begin{array}{c}13.6 \pm 7.8 \\
8.8 \pm 6.6 \\
\mathbf{0 . 0 0 1 * *}\end{array}$ \\
\hline $\begin{array}{l}\text { Diabetes } \\
\text { Yes (No:17) } \\
\text { NO (No:89) } \\
\text { p value }\end{array}$ & $\begin{array}{c}154.3 \pm 17.0 \\
127.0 \pm 19.5 \\
<\mathbf{0 . 0 0 1} * *\end{array}$ & $\begin{array}{l}15.8 \pm 7.5 \\
9.4 \pm 6.9 \\
<\mathbf{0 . 0 0 1 * *}\end{array}$ \\
\hline $\begin{array}{l}\text { Fatigue } \\
\text { Yes (No: 68) } \\
\text { NO (No:38) } \\
\text { p value }\end{array}$ & $\begin{array}{c}137.1 \pm 21.2 \\
121.2 \pm 18.3 \\
<\mathbf{0 . 0 0 1} * *\end{array}$ & $\begin{array}{l}12.4 \pm 7.5 \\
6.8 \pm 5.6 \\
<\mathbf{0 . 0 0 1} * *\end{array}$ \\
\hline $\begin{array}{l}\text { Anxiety } \\
\text { Yes (No: } 54) \\
\text { NO (No: } 52 \text { ) } \\
\text { p value }\end{array}$ & $\begin{array}{c}139.1 \pm 21.1 \\
123.3 \pm 19.1 \\
<\mathbf{0 . 0 0 1 * *}\end{array}$ & $\begin{array}{l}13.1 \pm 7.3 \\
7.6 \pm 6.5 \\
<\mathbf{0 . 0 0 1 * *}\end{array}$ \\
\hline $\begin{array}{l}\text { Insomnia } \\
\text { Yes (No:40) } \\
\text { NO (No:66) } \\
\text { p value } \\
\end{array}$ & $\begin{array}{c}143.5 \pm 20.5 \\
124.0 \pm 18.8 \\
<\mathbf{0 . 0 0 1 * *}\end{array}$ & $\begin{array}{l}14.7 \pm 6.8 \\
7.8 \pm 6.5 \\
<\mathbf{0 . 0 0 1 * *} \\
\end{array}$ \\
\hline $\begin{array}{l}\text { Musculoskeletal disorders } \\
\text { Yes (No:46) } \\
\text { NO (No: 60) } \\
\text { p value }\end{array}$ & $\begin{array}{c}140.8 \pm 18.0 \\
124.8 \pm 21.4 \\
<\mathbf{0 . 0 0 1} * *\end{array}$ & $\begin{array}{c}11.6 \pm 7.8 \\
9.5 \pm 6.9 \\
0.14\end{array}$ \\
\hline $\begin{array}{l}\text { Vision problems } \\
\text { Yes (No: 37) } \\
\text { NO (No: 69) } \\
\text { p value }\end{array}$ & $\begin{array}{c}136.5 \pm 23.6 \\
128.5 \pm 19.9 \\
0.06\end{array}$ & $\begin{array}{c}13.2 \pm 8.6 \\
8.9 \pm 6.4 \\
\mathbf{0 . 0 0 3} * *\end{array}$ \\
\hline
\end{tabular}

**Highly statistically significant. 
Table (4) showed that teachers who had hypertension and diabetes and those who had complaints of headache, fatigue had statistically significant higher mean score of OSI and BDI than those who didn't have these conditions. Teachers who suffered from musculoskeletal disorders showed highly significant mean score of OSI, while those who suffered from vision problems showed highly significant mean score of BDI.

Table (5): Correlations between Occupational Stress Index (OSI) mean score (total and sub-scales) and Beck Depression Inventory score (BDI).

\begin{tabular}{|l|c|c|}
\hline \multirow{2}{*}{\multicolumn{1}{|c|}{ Occupational stressors }} & \multicolumn{2}{c|}{$\begin{array}{c}\text { Beck Depression Inventory } \\
\text { (BDI) }\end{array}$} \\
\cline { 2 - 3 } & $\mathbf{r}$ & p value \\
\hline OSI total & 0.56 & $<\mathbf{0 . 0 0 1 * *}$ \\
\hline Role Overload & 0.4 & $<\mathbf{0 . 0 0 1 * *}$ \\
\hline Role ambiguity & 0.4 & $<\mathbf{0 . 0 0 1 * *}$ \\
\hline Role Conflict & 0.5 & $<\mathbf{0 . 0 0 1 * *}$ \\
\hline Unreasonable group \& & 0.5 & $<\mathbf{0 . 0 0 1 * *}$ \\
\hline Political pressures & & 0.1 \\
\hline Responsibility for persons & 0.15 & $<\mathbf{0 . 0 0 1 * *}$ \\
\hline Under participation & 0.27 & $<\mathbf{0 . 0 0 1 * *}$ \\
\hline Powerlessness & 0.41 & 0.13 \\
\hline Poor peer Relations & 0.14 & $<\mathbf{0 . 0 0 1 * *}$ \\
\hline Intrinsic impoverishment & 0.41 & $<\mathbf{0 . 0 0 1 * *}$ \\
\hline Low status & 0.40 & $<\mathbf{0 . 0 0 1 * *}$ \\
\hline Strenuous working & 0.47 & $\mathbf{0 . 0 1 *}$ \\
\hline Unprofitability & 0.23 & \\
\hline
\end{tabular}

*: Statistically significant $\quad * *$ : Highly statistically significant

Table (5) showed statistically significant positive correlations between OSI (total and all its subscales scores) and (BDI) scores except for responsibility for persons and poor peer relations. 


\section{Discussion}

Teaching is a physically and mentally challenging occupation. Teachers are continuously exposed to stress because of using a lot of energy in their daily work in the classroom, in addition to personal and familial commitments. Prolonged exposure to stress leads to psychological problems like depression and anxiety (Wang et al., 2017). The current study showed that $100 \%$ of studied school teachers suffered from occupational stress (OS), $55.7 \%$ of them have moderate stress while $28.3 \%$ and $16 \%$ had mild and severe stress respectively (Table1). More than $30 \%$ of the studied population had depression symptoms, $14.2 \%$ of them had moderate depression symptoms while $19.8 \%$ had mild one and a positive correlation between occupational stress and depression symptoms was found among them (Table 1,5). These results were consistent with that of Desouky and Allam 2017 who studied Egyptian school teachers using OSI and BDI and found that the prevalence of occupational stress was $100 \%$ and depression symptoms were $23.2 \%$.

As regards the effect of age and years of experience on the occurrence of occupational stress, the present study showed that more than 20 years of experience had higher mean of depression symptoms than others but did not reach a statistical significant level (Table 2). These results were similar to that was detected by Qadimi and Praveena, 2013 in their study on influence of age on job burnout and occupational stress among high school teachers, Paripex, India; and İpek et al., 2018 in their study on the relationship between occupational stress and teacher; who found no significant relationship between occupational stress and both of age and teaching experience duration among teachers at preparatory and secondary schools.

Regarding gender, there was statistically significant higher mean stress score among female teachers compared to males ( $\mathrm{p}$ value was 0.04 ) (Table2). Similarly, Michael et al., 2009; Jan et al., 2013 demonstrated that OS levels were higher among females than males and attributed that to their exposure to multiple stressors such as home and family duties, in addition to workplace responsibilities and they were not able to cope effectively with stress like males. In contrast, İpek et al., 2018 concluded that gender had no effect on stress level between Turkish teachers. 
On dividing school teachers according to the grades which they taught into primary, preparatory or secondary, the present study showed no statistically significant differences between them (Table 2). These results may be due to the nature of the national system of teaching in Egypt, because all levels of grades are facing the same problems and deficits in their educational system.

When dividing teachers according to school type, the current study detected that governmental school teachers significantly suffered more from occupational stress and depression symptoms than private ones (Table 2). These results were in resemblance to Doss et al., 2018, when they did a comparative study to determine the occupational stress level and professional burnout in special school teachers working in private and government schools; they concluded that the Indian governmental school teachers were more significantly stressed in comparison to private school teachers mainly due to poor working condition, bad students' behavior and excess student' classroom number. The study done by Sobhy, 2019 in Egypt demonstrated that the average Egypian classroom density was 47.5 students/ classroom which was higher than the average in other countries such as India and China.

The reasons as previously demonstrated by Sarah, 2008 were that teachers working in governmental school are suffering from poor school facilities, excess student number in the class, poor parental role especially when they are of low level of education as they are completely dependent on teacher, in addition to low salaries, which obliged them to do extra-private work to compensate and improve their socioeconomic status.

Chronic exposure to stress resulted in stress related physical symptoms like tiredness, headache, gastrointestinal disturbance, chest and back pain (Glise et al., 2014). This may explain why fatigue was significantly higher among teachers with high means of stress and depression than others (Table 4); which were consistent with the results of Rose et al. 2017 who reported that fatigue was one of the crucial indicators of burnout and depression and was associated with work-related stressors such as work overload, frequent overtime hours, conflicts with boss or with other colleagues. 
Hypertension and diabetes may be caused or aggravated by stress. Liu and his colleagues, 2017 showed that hypertensive patients had a higher incidence of psychosocial stress when compared to normotensive patients. Also Nyberg et al., 2014 showed an association between occupational stress and increased risk of diabetes among those with healthy and unhealthy lifestyle habits. These might explain why we found that teachers in the current study with hypertension and diabetes had high mean levels of scores of OSI and BDI (Table 4).

There were multiple occupational stressors (OS) that lead to the occurrence of occupational stress and affect teachers' mental and physical health. For this reason, we used occupational stress index subscales to determine the most stressing factors causing OS (Table3). The present study detected that overload was the most prominent stressor (Mean \pm SD 17.4 \pm 3.5 ) (Table 3). Overload arises from performing too much work and overcrowded curriculum that needs to be fulfilled in a short time and in the presence of insufficient number of teachers and limited resources. Paper work, lesson planning, student follow up, teaching many academic grades in the same educational year aggravated role overload.

These results were similar to what was detected by Punia and Balda 2016 in their study on occupational stress among teachers in different cultural zones of Haryana who found that role overload and role ambiguity were the most stressful items to teachers. Role conflict came after role overload in causing stress among school teachers (Table 3) that occurred when there were contradictory and unclear instructions from authorities that interfere with their teaching and working methods (Dhar and Magotra, 2018).

Thecurrentstudyfoundunreasonable group and political pressures were the third occupational stressors among teachers (Table3). Teachers have to perform work unwillingly and violate policies especially when politics affect organizational decisions rather than performance (Larson, 2004; Chang and $\mathrm{Lu}, 2007)$. These results were consistent with that of Rani and Singh, 2012; who detected that role overload was the highest occupational stressors among school teachers followed by role conflict and unreasonable group and political pressures.

As regards the differences between 
private and governmental school teachers, powerlessness, poor peer relations, intrinsic impoverishment and low status were significantly higher among governmental school teachers compared to private ones (Table 3). Governmental school teachers stated that they became more stressed when their suggestions and opinions were not properly followed during important decisions. As well, they suffer from lack of positive relationship and cooperation with their colleagues and insufficient mutual cooperation and team spirits, in addition to the feeling of low social status and self-esteem because that their higher authorities did not concern to their post and work (Kabito and Wami, 2020).

On the other hand, the private school teachers in the current study had highly significant subscale of high responsibility for person than governmental teachers, this may be due to teachers in private schools are highly responsible for efficiency and competency of their students, improvement and maintenance of school progress and prosperity to maintain competition with other private educational organizations. They also have to meet expectation of parents, students and their administrators as reported by Kapse and his colleagues 2010.

Positive correlations were detected in the present work between all occupational stress subscales and depression symptoms except responsibility for persons and poor peer relations (Table5). These were comparable to the results detected by Moreno-Abril et al. 2007, Holeyannavar and Itagi 2010 who found positive significant correlations between occupational stressors and depression symptoms.

\section{Conclusion}

All teachers in the present work had occupational stress that was related to several occupational stressors. Stress and depression symptoms lead to different complaints as headache, fatigue, insomnia, anxiety, musculoskeletal and vision problems which were serious consequences of exposure to occupational stress.

Recommendations: So taking care of teachers physically and psychologically is essential for their wellbeing and their productivity. Periodic medical examination is recommended for early detection 
of somatic manifestations, and psychological intervention of cases with stress and depression symptoms. Offering stress coping strategies programs on organizational and national basis is important to alleviate stress and maintain mental and physical wellbeing of teachers for better performance. Therefore, their problem needs a collaborative cooperation among different sectors.

\section{Conflict of interest}

The authors declared that there was no conflict of interest

\section{Funding}

This research did not receive any specific grant from funding agencies in the public, commercial, or not-forprofit sectors.

\section{Acknowledgment}

We acknowledge all school managers and participants who participated in this study.

\section{References}

1. Asa FT and Lasebikan VO (2016): Mental health of teachers: teachers' stress, anxiety and depression among secondary schools in Nigeria . Int Neuropsychiatr Dis J; 7 (4): 1-10. DOI: 10.1016/j.jegh.2017.06.002.

2. Chang $\mathrm{K}$ and $\mathrm{Lu} \mathrm{L}$ (2007): Characteristics of organizational culture, stressors and wellbeing: The case of Taiwanese organizations. J Manag
Psychol; 22(6):549-68.

3. Chan YH (2003): Biostatistics102: Quantitative Data - Parametric \& Non-parametric Tests. Singapore Med J; 44(8): 391-6.

4. Desouky D and Allam H (2017): Occupational stress, anxiety and depression among Egyptian teachers. J Epidemiol Glob Health; 7:191-8. DOI:10.1016/j.jegh.2017.06.002.

5. Dhar N and Magotra R (2018): A Study of Occupational Stress Among Teachers Teaching in JKBOSE \& CBSE in Jammu District: A Comparative Study. Intern J Adv Res Edu Tech (IJARET); 5,1.Available at: https:// www.semanticscholar.org/paper/A-Study-ofOccupational-Stress-Among-Teachers-in-\%26Dhar-Magotra/85c9a76e400126ab9016988f10 09a3007a07119f

6. Doss C, Joyce Rachel J, Jarrar M, AbuMadini MS and Sakthivel M (2018): A Comparative Study to Determine the Occupational Stress Level and Professional Burnout in Special School Teachers Working in Private and Government Schools. Glob J Health Sci; 10, (3):42. DOI: 10.5539/gjhs. v10n3p42.

7. Glise K, Ahlborg G J and Jonsdottir IH (2014): Prevalence and course of somatic symptoms in patients with stress-related exhaustion: does sex or age matter. BMC Psychiatry; 23 (14):118. DOI: 10.1186/1471-244X-14-118.

8. Greenglass ER and Burke RJ (2003): Teacher stress. In M. F. Dollard, A. H. Winefield, \& H. R. Winefield (Eds.), Occupational stress in the service professions ( 213-236). New York, NY: Taylor and Francis. DOI:10.1016/j. sbspro.2014.03.421.

9. Harvey SB and Wessely S (2013): How should functional somatic syndrome be diagnosed? Int J Behav Med; 20: 239-41.

10. Holeyannavar PG and Itagi SK (2010): Stress and health status of primary school teachers. Karnataka. J Agri Sci; 23(4):620-4.

11. İpek H, Akacy A, Atay SB, Berber G, Karalik $\mathrm{T}$ and Yilmaz TS (2018): The Relationship Between Occupational Stress And Teacher. 
Self-Efficacy: A Study With EFL Instructors AJESI - Anadolu J Edu Scie Intern; 8(1): 12650. DOI: 10.18039/ajesi.393945

12. Jan DT, Malik MH and Ahmad JA (2013): Study of social and family role stress among primary school teachers of district budgam, j \& $\mathrm{k}$. india. J Educ Res Essays; 1(1):1-4.

13. Kabito GG and Wami SD (2020): Perceived work-related stress and its associated factors among public secondary school teachers in Gondar city: a cross-sectional study from Ethiopia. BMC Res Notes 13; 36. https:doi. org/10.1186/s13104-020-4901-0 .Available at :https://bmcresnotes.biomedcentral.com/ articles/10.1186/s13104-020-4901-0

14. Kapse M, Pathak A and Sharma S (2010): Occupational stress among female teaching professionals and its effect on home environment at Indore city. Sugyaan, Management journal of Siva Sivani institute of management, II (I):5966. Cited in Jadav, D. (2018). A Comparative Study of the Depression among Sahayak and Permanent Teachers .IJRAR; 5(3). Available at: http://ijrar.com/upload_issue/ijrar_issue_1040. pdf.

15. Larson LL (2004): Internal auditors and job stress. Manag Audit J; 19(9):1119-30.

16. Liu MY, Li N, Li WA and Khan H (2017): Association between psychosocial stress and hypertension: a systematic review and metaanalysis. Neurol Res; 39(6):573-80. DOI: 10.1080/01616412.2017.1317904.

17. Liu XS and Ramsey J (2008): Teachers' job satisfaction: Analyses of the teacher followup survey in the United States for 2000-2001 [Electronic version]. Teach Teach Educ; 24: 1173-84. DOI: 10.1016/j.tate.2006.11.010.

18. Michael G, Anastasios S, Helen K, Catherine $\mathrm{K}$ and Christine K (2009): Gender differences in experiencing occupational stress: The role of age, education and marital status. Stress Health; 25: 397 - 404. DOI: 10.1002/smi.1248.

19. Moreno-Abril O, Luna-del-Castillo JD, Ferna'ndez-Molina C, Jurado D, Gurpegui M, et al. (2007): Factors associated with psychiatric morbidity in Factors associated with Psychiatric morbidity in Spanish school teachers. Occup Med; 57:194-200. DOI:10.1093/occmed/ kqm013.

20. Moreno-Abril O, Luna-del-Castillo JD, Ferna'ndez-Molina C, Jurado D, Gurpegui, et al. (2007): Factors associated with psychiatric morbidity in Factors associated with Psychiatric morbidity in Spanish school teachers. Occup Med; 57:194-200.

21. Mursali A, Basuki E and Dharmono S (2009): Relationship between noise and job stress at a private thread spinning company. Univ Med; 28:8-16. DOI:10.18051/UnivMed.2009.v28.816.

22. Naghieh A, Montgomery $\mathrm{P}$, Bonell CP, Thompson MandAber JL(2015): Organizational interventions for improving wellbeing and reducing work-related stress in teachers. Cochrane Database of Systematic Reviews; 4. DOI: 10.1002/14651858.CD010306.pub2.

Available at :https://researchonline.lshtm. ac.uk/id/eprint/2548657/1/Organisational $\% 20$ interventions \% 20 for $\% 20 \mathrm{improving}$ GREEN\%20VoR.pdf

23. Nyberg ST, Fransson EI, Heikkilä K, Ahola K, Alfredsson L et al., (2014): Job strain as a risk factor for type 2 diabetes: a pooled analysis of 124,808 men and women. Diabetes Care; 37(8):2268-75. DOI: $10.2337 / \mathrm{dc} 13-2936$.

24. Punia N and Balda S (2016): Occupational Stress among Teachers in Different Cultural Zones of Haryana. Remarking; 3: 56-9. Available at :https://scirp.org/reference/referencespapers. aspx ?referenceid $=1914075$.

25. Qadimi A and Praveena KB (2013): Influence of Age on Job Burnout and Occupational Stress among High School Teachers, Paripex - Ind J Res; 2(8): 80-3.

26. Rani $G$ and sing $H$ (2017): An Empirical Assessment on Occupational Stress among School Teachers. International Journal of Education and Psychological Research (IJEPR); 
6, (4): 47-51.

27. Rose DM, Seidler A, Nübling M, Latza U, Brähler E,et al., (2017): Associations of fatigue to work-related stress, mental and physical health in an employed community sample. BMC Psychiatry; 17(1):167. DOI: 10.1186/ s12888-017-1237-y.

28. Sarah H (2008): The Informal Education Sector in Egypt: Private Tutoring between State, Market, and Civil Society. Working Paper 88, Department of Anthropology and African Studies, Johannes Gutenberg-Universität. Available at :https://openscience.ub.unimainz. de/bitstream/20.500.12030/391/1/1618.pdf

29. Schwarzer R and Hallum S (2008): Perceived teacher self-efficacy as a predictor of job stress and burnout: Mediation analysis. Appl Psychol;
An International Review, 57:152-71. DOI: 10.12691/education-4-7-8.

30. Sobhy H (2019): Expensive classrooms, poor learning: The imperatives of reforming school construction in Egypt. Alternative Policy Solutions: Policy Paper. Available at: http://hdl. handle.net/21.11116/0000-0006-0B7C-4.

31. Wang Z Liu H, Yu H, Wu Y, Chang S and Wang L (2017): Associations between occupational stress, burnout and well-being among manufacturing workers: mediating roles of psychological capital and self-esteem. BMC Psychiatry; 17(1):364.

32. Yang $\mathrm{X}, \mathrm{Ge} \mathrm{C}, \mathrm{Hu} \mathrm{B}, \mathrm{Chi} \mathrm{T}$ and Wang $\mathrm{L}$ (2009): Relationship between quality of life and occupational stress among teachers. Public Health; 123(11): 750-5. 